\title{
Reptilia, Squamata, Iguanidae, Enyalioides touzeti Torres-Carvajal, Almendáriz, Valencia, Yañez-Muñoz and Reyes, 2008: Distribution extension and first country record for Peru
}

\author{
Pablo J. Venegas ${ }^{1 *}$, Margot Cuyos $^{1}$ and Karen Y. Siu-Ting ${ }^{2}$ \\ 1 División de Herpetología del Centro de Ornitología y Biodiversidad (CORBIDI). Santa Rita 117, Huertos de San Antonio. Surco, Lima, Perú. \\ 2 Museo de Historia Natural de la Universidad Nacional Mayor de San Marcos, Departamento de Herpetología. Avenida Arenales 1256. Lima, Perú. \\ * Corresponding author: sancarranca@yahoo.es
}

\begin{abstract}
The current article provides the first country record of Enyalioides touzeti in Peru. This new record extends the known species distribution ca. $52 \mathrm{Km} \mathrm{SW}$ from the southernmost record at the Province of El Oro, Ecuador, and increases the number of Enyalioides species in Peru to six.
\end{abstract}

The Neotropical iguanian lizard genus Enyalioides Boulenger, 1885 contains eight species known from the lowlands between Panama to Bolivia on both sides of the Andes (Torres-Carvajal et al. 2008). The highest diversity of the genus occurs in Ecuador with seven species (TorresCarvajal et al. 2008). In Peru, five species of Enyalioides (E. cofanorum, E. laticeps, E. microlepis, E. palpebralis, and E. praestabilis) have been reported from the Amazon lowlands (Carrillo and Icochea 1995; Duellman and Mendelson III 1995; Wiens and Etheridge 2003; Torres-Carvajal et al. 2008). The recently described Enyalioides touzeti is known from the Pacific slopes of southern Ecuador (TorresCarvajal et al. 2008). This species, along with E. heterolepis and E. oshaughnessyi, are the only species that inhabit the Pacific lowlands and western slopes of the Andes (TorresCarvajal et al. 2008).

The Tumbes region on north-western Peru hosts the southernmost populations of several species of amphibians and reptiles which occur from Central America through the Pacific lowlands and western Andean slopes of Colombia and Ecuador (Venegas et al. 2008). Tello (1998) presented the most complete herpetological work of the Tumbes region to date; where he reported Enyalioides microlepis, a species known only from the upper western Amazon Basin (Torres-Carvajal et al. 2008). Given the low probability of this record and since Tello (1998) did not cite voucher specimens, we reviewed his collections deposited at the Museum of Natural History of Universidad Nacional Mayor de San Marcos (MUSM) and at the Museum of Natural History of Universidad Ricardo Palma (URP) in Lima, Peru. We found four specimens of Enyalioides (an adult male and three juveniles) identified in the MUSM collection as E. microlepis by G. Tello. After thorough revision of the material, we concluded that the four specimens were not E. microlepis, but instead E. touzeti based on the characters described by Torres-Carvajal et al. (2008). Therefore, we formally report the first record of E. touzeti in Peru. One adult male (MUSM 17560; Figures 1 and 2) and three juveniles of Enyalioides touzeti (MUSM 17558, 17559, 17561; Figures 3 and 4) were collected in Quebrada Los Naranjos, Parque Nacional Cerros de Amotape, province of Zarumilla, Region of Tumbes (Figure 5), in February 1996 by G. Tello. Additionally, in a recent survey by the Centro de Ornitología y Biodiversidad (CORBIDI) at Parque Nacional Cerros de Amotape, one of us (M. Cuyos), collected a juvenile female of $E$. touzeti (CORBIDI 04517) at the locality of Campo Verde (0350’34.2”S, 80¹2'38.8”W; 740 m) (Figure 5).

A

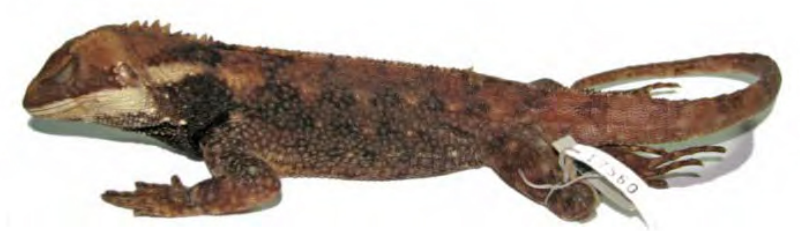

B

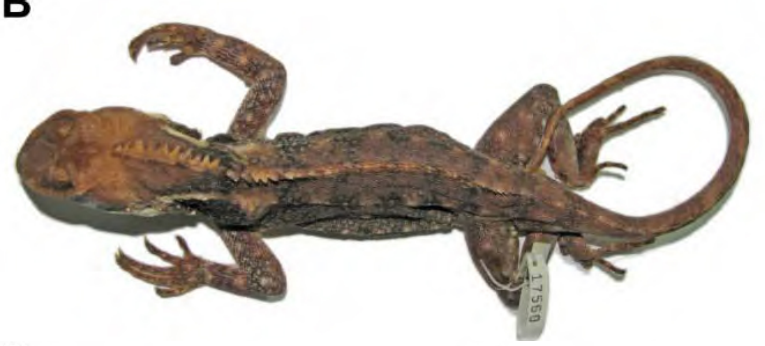

C

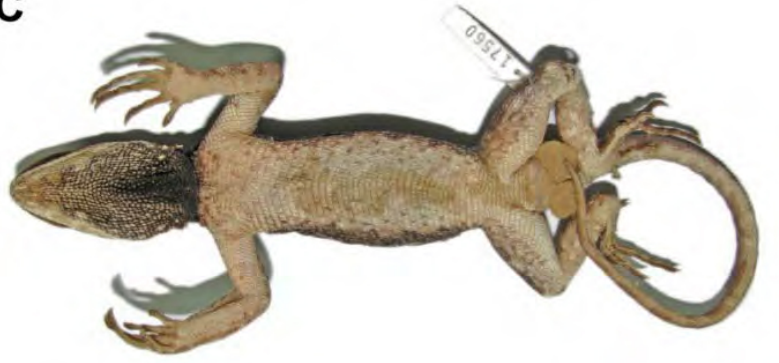

Figure 1. Lateral (A), dorsal (B) and ventral (C) views of the adult Enyalioides touzeti (MUSM 17560). 
A

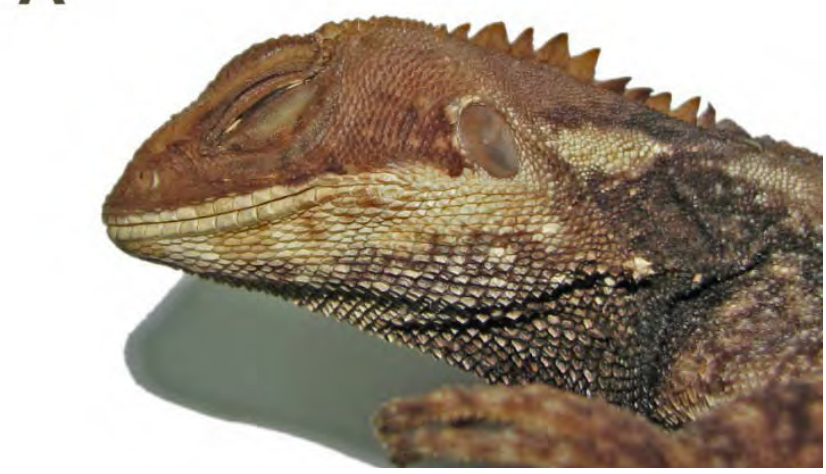

B

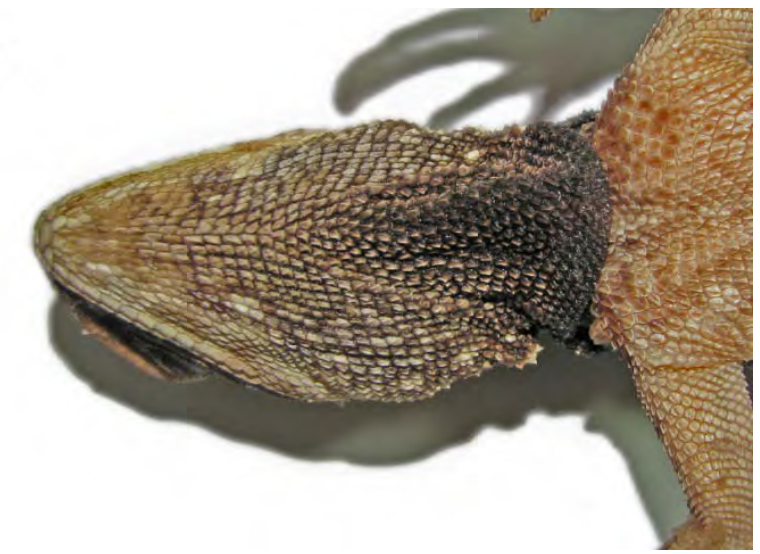

FIGURE 2. Lateral (A) and dorsal (B) views of the head of preserved adult male Enyaloides touzeti (MUSM 17560).
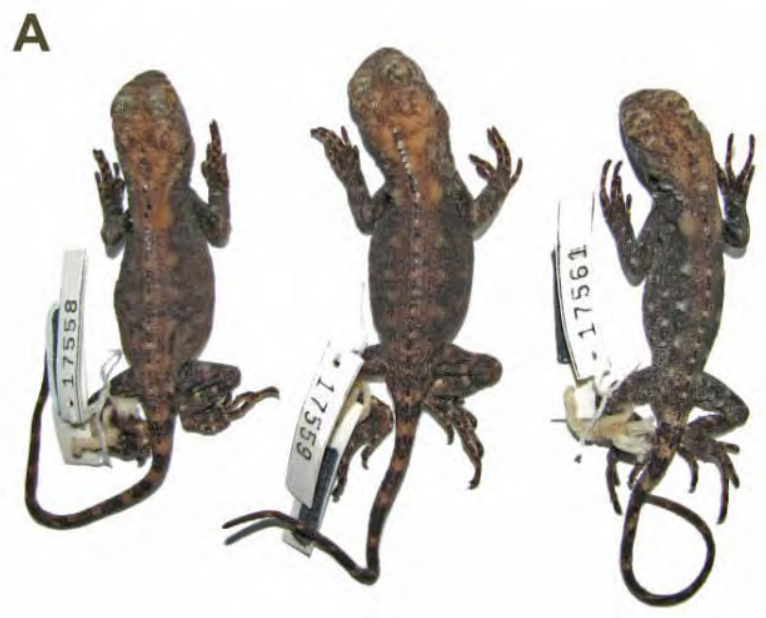

B

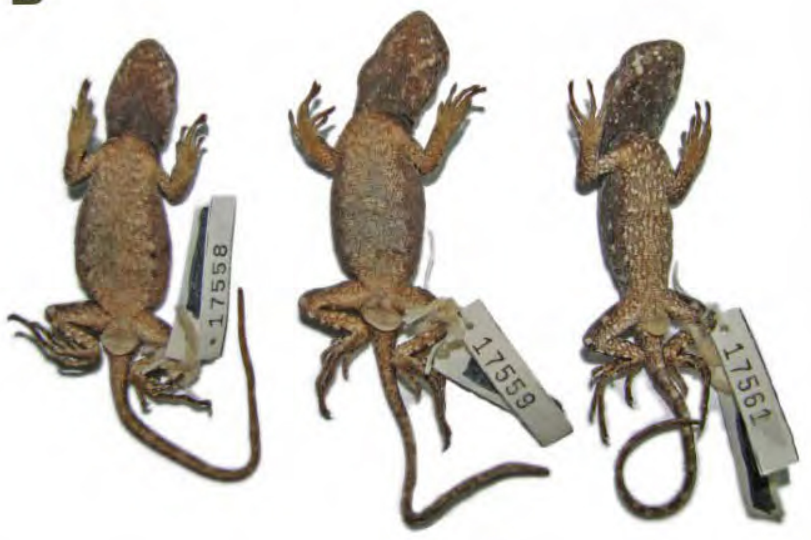

FIGURE 3. Dorsal (A) and ventral (B) views of three juveniles males of Enyalioides touzeti (MUSM 17558, 17559, 17561).

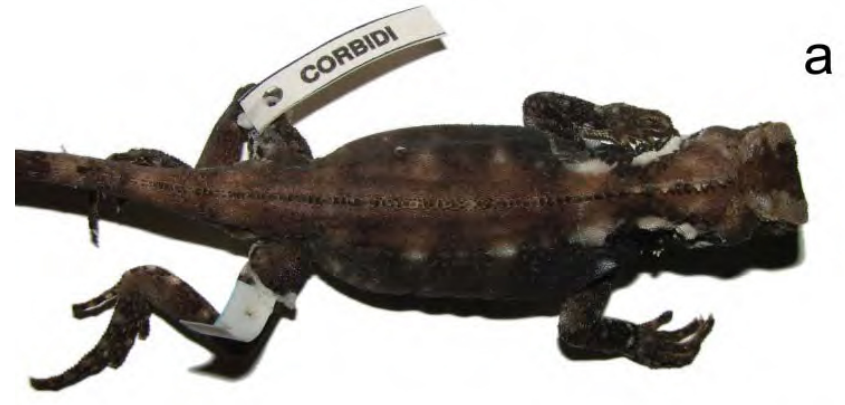

a

b

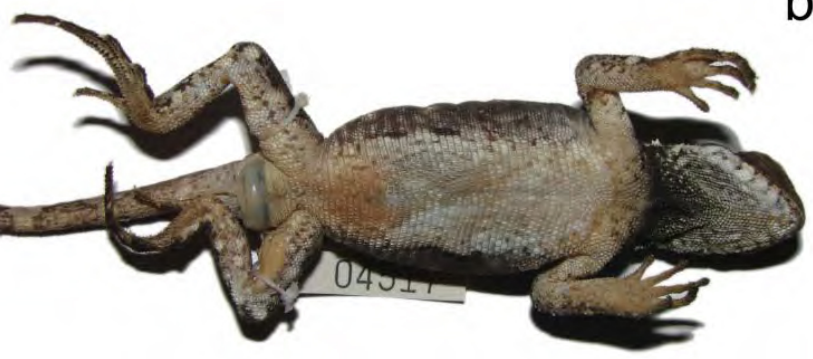

Figure 4. Dorsal (A) and ventral (B) views of a juvenile female of Enyalioides touzeti (CORBIDI 04517).

The adult male (MUSM 17560, snout-vent length $=136$ $\mathrm{mm}$ ) agrees with the description of $E$. touzeti presented by Torres-Carvajal et al. (2008) by having: the body flanks conspicuously folded, small paravertebral scales, each with a conspicuous medial keel, scales on body flanks homogeneous in size, and a black patch covering the majority of the gular surface (Figure $1 \mathrm{C}$ and $2 \mathrm{~B}$ ). Furthermore, the dorsal coloration of the adult specimens (Figure $1 \mathrm{~A}$ and $\mathrm{B}$ ) is very similar to the male paratype of $E$. touzeti (EPN 10735) in the original description (see Figure 2B in Torres-Carvajal et al. 2008). The life coloration of the juvenile female of $E$. touzeti (CORBIDI 04517, snout-vent length $=82 \mathrm{~mm}$ ) had reddish brown rhomboidal blotches on a greenish brown background on the dorsum and greenish brown flanks with pale spots; the dorsal surface of the head was reddish brown, the sides of the head greenish brown with a conspicuous labial bar that extends to the neck insertion; the ventral surface is grayish white and the gular region black (Figure 4). Although the shape and order of the scales is difficult to observe in the juvenile specimens, all of these have the black patch covering partially (MUSM 17599, 17558 and CORBIDI 04517) and completely (MUSM 17561) the gular region (Figure 2). These four juvenile $E$. touzeti have a SVL between 48 and $82 \mathrm{~mm}$. Torres-Carvajal et al. (2008) describe the life coloration of a juvenile female of the type series of $E$. touzeti and mentioned a white venter without the black patch on the throat and the same ventral coloration for the adult females. However, we found that our juvenile female specimen (CORBIDI 04517) presents a black patch on the throat (Figure 4B). The ventral coloration of the four juvenile specimens ( 1 female and 3 males) reported in this work (Figure 3B and Figure 4B), suggests that the black throat coloration could be a geographic variation that can be present in females.

Enyalioides touzeti was previously known from the Pacific slopes of the southern Andes of Ecuador, at 


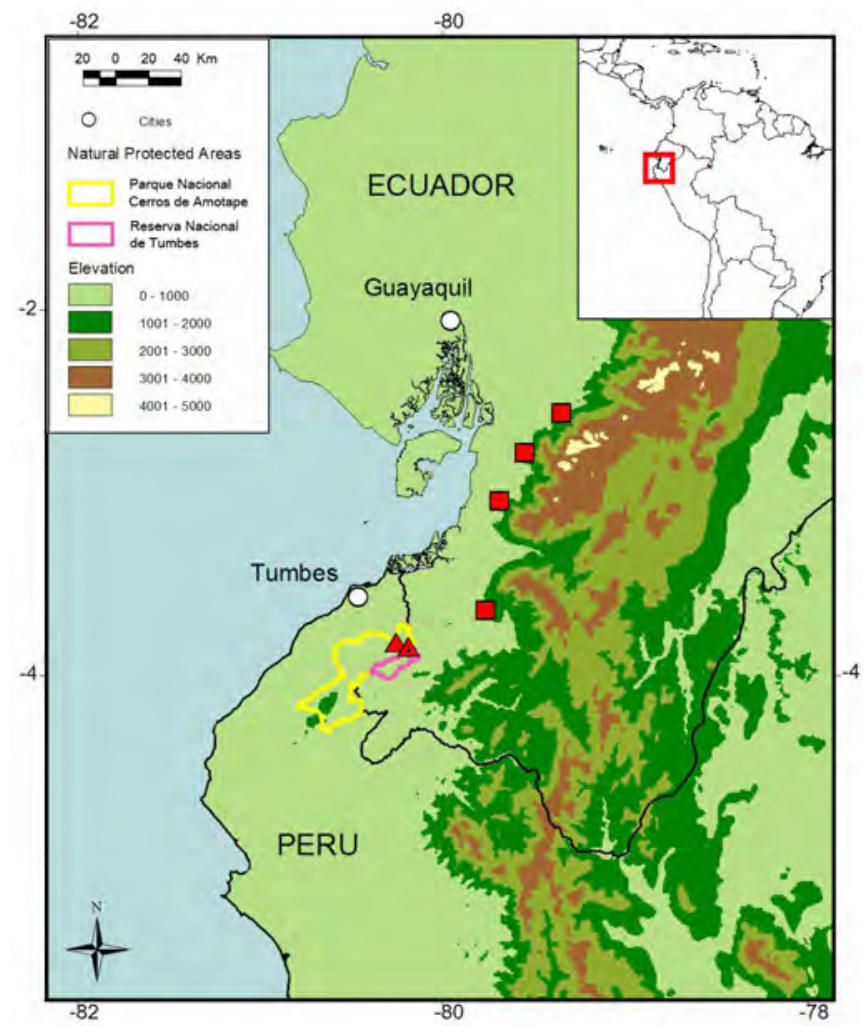

FIGURE 5. Map of south-western Ecuador and north-western Peru showing the general distribution of Enyalioides touzeti in the area. Red squares are the four Ecuadorian localities reported by Torres-Carvajal et al. (2008). Red triangles correspond to the two new localities reported in this work: plain red triangle stands for Campo Verde and red triangle with inner black spot stands for Quebrada Los Naranjos. elevations between 300 and $700 \mathrm{~m}$, in the provinces of Azuay, Cañar, and El Oro (Torres-Carvajal et al. 2008). These new records extend the known distribution range of $E$. touzeti by approximately $52 \mathrm{Km} \mathrm{SW}$ airline $(52.2 \mathrm{Km}$ to Quebrada Los Naranjos and $51.8 \mathrm{Km}$ to Campo Verde, Figure 5), and increase the number of species of Enyalioides in Peru to six, making Peru the second country in reference to Enyalioides diversity in the world (Ecuador: seven species; Peru: six; Colombia: five; Brazil: two; Panama: one; and Bolivia: one) (Torres-Carvajal et al. 2008).

ACKNowledgments: We thank J. Cordova and C. Aguilar for giving access to the scientific collection at MUSM; and to Victor Morales at URP.

\section{Literature Cited}

Carrillo, N. and J. Icochea. 1995. Lista taxonómica preliminar de los reptiles vivientes del Perú. Publicaciones del Museo de Historia Natural UNMSM (A) 49: 1-27.

Duellman, W.E. and J.R. Mendelson III. 1995. Amphibians and Reptiles from northern Departamento de Loreto, Peru: taxonomy and biogeography. The University of Kansas Science Bulletin 55: 329-376.

Tello, V.G. 1998. Herpetofauna de la Zona reservada de Tumbes; p. 8187. In W.H. Wust (ed.). La Zona Reservada de Tumbes: Biodiversidad y Diagnóstico Socioeconómico. Lima: Edit. Australis.

Torres-Carvajal, O., A. Almendáriz, J. Valencia, M. Yañez-Muñoz, and J.P. Reyes. 2008. A new species of Enyalioides (Iguanidae: Hoplocercinae) from southwestern Ecuador. Papeis Avulsos de Zoologia 48(20): 227235.

Venegas, P.J., K. Siu-Ting, and J.C. Jordan. 2008. Amphibia, Hylidae, Hypsiboas pellucens: First country record, Peru. Check List 4(2): 214 217.

Wiens, J.J. and R.E. Etheridge. 2003. Phylogenetic relationships of Hoplocercid lizards: coding and combination meristic, morphometric, and polymorphic data using step matrices. Herpetologica 59(3): 375398.

RECEIVED: April 2009

REVISED: May 2010

ACCEPTED: May 2010

PuBlished ONLINE: August 2010

EDITORIAL RESPONSIBILITY: Alejandro R. Giraudo 